The study on the substantiation of using sprouted beans flour enriched with iodine and selenium in the production of the sourmilk product was carried out. The relevance of this research was determined by the lack of sour-milk products for people suffering from endocrine disorders; the shortage of these products at the market reaches about $23 \%$ of the total manufacturing of produce. The study revealed that goat milk may be considered as the basis for the creation of a sour-milk product for special dietary consumption. Goat milk has a low content of $\alpha s 1-\alpha s 2-$ and a high content of $\beta$-casein fractions of proteins in comparison with cow milk. It was established that it is rational to use the strains of cultures of Lactobacillus acidophilus and Bifidobacterium lactis organisms in the ratio of 2:1 at the concentration of flour of sprouted beans in the amount of $2 \%$ of the product weight. The samples have a clean, sour-milk smell, sour-milk flavor, dense clot, and $25.8 \%$ more bifidobacteria cells compared to the control sample.

The dependences of a change in active acidity, effective viscosity on the use of various concentrations of sprouted beans flour during the production of the sour-milk product were obtained. It was established that active acidity in the samples using 1.5; 2, and $2.5 \%$ is $4.68 ; 4.60$ and $4.58 \mathrm{pH}$ units (respectively), which is by $0.04 ; 0.12$ and $0.14 \mathrm{pH}$ units less than the control sample. The use of flour from sprouted beans in the amount of $1.5 . .2 .5 \%$ reduces the area of the hysteresis loop, which indicates more pronounced thixotropic properties of the sour-milk product structure in comparison with the control sample.

The obtained regularities are scientific grounds for the development of the formulation of the sour-milk item for a special dietary purpose with the preservation of organoleptic quality indicators that are usual for a consumer

Keywords: sprouted beans flour, selenium, iodine, chick-pea, soy, milk, bifidobacteria, sour-milk product

$$
\square
$$

UDC 637.441

DOI: $10.15587 / 1729-4061.2020 .209514$

\section{SUBSTANTIATING THE USE OF SPROUTED BEANS FLOUR IN THE PRODUCTION OF SOUR MILK PRODUCTS BASED ON GOAT MILK}

\author{
Y. B ile t sk a \\ $\mathrm{PhD}$, Associate Professor* \\ E-mail: ya.belecka@karazin.ua
}

T. R y z h k ov a

Doctor of Technical Sciences, Associate Professor Department of Processing Technology, Standardization

and Technical Service

Kharkiv State Zooveterinary Academy Akademichna str., 1, Mala Danylivka, Dergachivsky district, Kharkiv region, Ukraine, 62341

E-mail: rugkova.ua@gmail.com

V. B a be n k o

Doctor of Economic Sciences, Professor*

E-mail: vitababenko@karazin.ua

A. Krivtsova

$\mathrm{PhD}$ *

E-mail: anna.perepelytsia@karazin.ua

R. Plot nikova

$\mathrm{PhD}$

Department of Food Technology**

E-mail: raisa1786@icloud.com

O. $\mathbf{s}$ k y r d a

$\mathrm{PhD}$, Associate Professor

Department of Commodity and Examination of Goods**

E-mail: sheva-foreve@ukr.net

*Department of International E-commerce and Hotel\&Restaurant Business

V. N. Karazin Kharkiv National University

Svobody sq., 4, Kharkiv, Ukraine, 61002

**Kharkiv State University of Food Technology and Trade

Klochkivska str., 333, Kharkiv, Ukraine, 61051

\section{Introduction}

Today, great attention in the world is paid to the development of health-improving products [1]. In this case, the creation of products for people having dietary nutrition takes a special place. A promising direction in the creation of new food products is the combination of dairy and plant raw materials, which can make up for the shortage of necessary substances, important to our organism. Sour-milk products provide the body with proteins, carbohydrates, lipids, lactic-acid bacteria that positively contribute to intestine functioning, promoting the growth of favorable microflora and removal of opportunistic pathogenic microorganisms [2]. However, the problem of microelements deficiency, which was detected in $34 \%$ of the population of Europe, remains unresolved [3-5]. The range of food products for people suffering from endocrine disorders in the country is not wide enough and is about $2.0 \%$. 
Sour-milk products may be considered as a basis for the development of specialized wellness products, which will provide the human organism not only with proteins, carbohydrates, lipids, and lactic acid bacteria but also with iodine and selenium. The shortage of sour-milk products for people suffering from endocrine disorders is about $23 \%$ of the total production [6]. The problem of developing the formulations and technologies of sour-milk products enriched with iodine and selenium is very acute and relevant. The use of flour of sprouted beans enriched with iodine and selenium during the production of a sour-milk vegetable product is an important task, the implementation of which will expand the range of food products for people suffering from endocrine disorders.

\section{Literature review and problem statement}

Analysis of literary sources revealed that the range of sour-milk products is aimed at the development of formulations and product technologies of cow milk-based products $[7,8]$. Scientific papers $[9,10]$, in which scientists study unconventional types of milk, appear nowadays. It was considered relevant to pay attention to clarification on how milk of the mare, camel, goat, and other animals differs from cow milk and how useful and "attractive" it is for the production of specialized sour-milk products.

It was established in paper [11], where the scientists studied the chemical composition of mare milk, that it differs significantly from the composition of cow milk. It contains half as much protein and fat, almost 1.5 times as much lactose than cow milk. The acidity of mare milk is quite low. It belongs to the milk of the albumin group - the proportion of casein in it accounts for $50 \ldots . .60 \%$ of the total amount of proteins. Analyzing the data on the chemical composition of mare milk, it is possible to predict that it is inappropriate to use for the production of specialized sour-milk products A dense clot will not be formed during clotting of mare milk. Protein will be deposited in the form of delicate small flakes; consequently, a sour-milk product will have a liquid consistency, that is, organoleptic indicators that are unusual for a consumer. This will decrease the demand for this product and economic effect from the production.

Sheep milk is more attractive for its chemical composition in terms of the formation of a dense clot in a sour-milk product [12]. The total density of sheep milk was found to be higher than that of cow milk. When using the strains of microorganisms - acidophiles and bifidobacteria in the amount of $2 \%$, a sour-milk product based on sheep milk has a dense clot and organoleptic parameters that are usual for consumers [13]. The disadvantage of using sheep milk in the sour-milk specialized product is high fat content, the average content of which is in the range of $12 \ldots 13 \%$. Products will be useful for improving appetite, at anemia, while it is better not to use them at gastrointestinal diseases, ulcers, gastritis, and colitis.

To produce a specialized sour-milk product, camel milk is optimal in terms of biological effects on the organism and the usual organoleptic indicators. The clinical studies [14, 15] of daily consumption of the milk product were conducted within 30 days. It was found that the camel milk-based product has usual organoleptic parameters, elevated content of amino acids. However, camel milk in its composition contains antibacterial substances that slow down the reproduction of microorganisms - acidophiles and bifidobacteria. The use of camel milk during the production of sour-milk is certainly of interest to scientists and is useful for people with dietary nutrition. The downside is that camel milk is scarce in Europe, which indicates an inexpedient use of this type of milk.

The solution to the above-mentioned problems can be the use of goat milk as the basis for the creation of specialized sour-milk products [16-18].

It was proved in paper [16] that goat milk is recommended for people with specialized nutrition and those who have gastrointestinal diseases. Goat milk has its advantages over other kinds of milk and is useful for people due to the optimal chemical composition and low fat content [17]. The results of the research into the development of the technology of goat milk-based kefir using the iodine-containing additive "Elamn" are presented in paper [18]. It was determined that the additive influences the intensity of the sour milk fermentation process and reduces the time of formation of a dense clot, at the same time enriching the product with iodine. The disadvantage of this technology is the enrichment of the sour-milk product only with iodine. The possibility of producing the sour-milk product based on goat milk was explored and the developed products have usual organoleptic characteristics and increased vitamin content, however, these indicators fluctuate in a different breed of goats, which gave milk. Articles [19,20] described that goat milk protein is digested better than that of cow milk due to the rational ratio of alpha-s and $\beta$-casein fractions. The use of milk with decreased content of alpha-s1- casein is optimal for the production of specialized sour-milk products. Such milk has a pronounced allergic effect, but its content influences the structure forming indicators of the sour-milk product, as well as the content of $\alpha$ s 2 - and $\beta$-casein fraction.

There arises a need to study the content of major fractions of proteins in cow and goat milk and to explore the dependences of the content of $\alpha s 1-, \alpha s 2$-and $\beta$-casein fraction on the technological properties of the sour-milk product.

It is known [21-23] that bifidobacteria develop more slowly in goat milk than in cow milk. In paper [24], it was proved that combined leavens have higher biochemical activity and stability in comparison with the leavens produced in monocultures.

One of the causes of poor growth of bifidobacteria is a different composition of the casein fraction, which forms favorable conditions for reproduction only after the partial hydrolysis of casein. Casein splitting resulted in the formation of polypeptides, glycopeptides, amino sugars that stimulate the growth of bifidobacteria. The solution to this problem is possible by increasing the contents of bifidobacteria, due to additional use of cultures of Lactobacillus acidophilus and Bifidobacterium lactis.

The research into their influence on a change in quality indicators of the sour-milk product at different concentrations of sprouted beans flour and the study of a change in active acidity and effective viscosity is a necessary task. Since there are not enough data on the application of sprouted beans flour, enriched with iodine and selenium during the production of a sour-milk product, it is necessary to deepen and expand the research in this direction.

\section{The aim and objectives of the study}

The aim of this study is to substantiate the use of sprouted beans flour during the production of the sour-milk product based on goat milk.

To accomplish the aim, the following tasks have been set:

- to explore the content of the basic fractions of proteins in goat and cow milk of and study their influence on the 
technological properties of a sour-milk product, to explore the influence of the content of cultures of Lactobacillus acidophilus and Bifidobacterium lactis on a change in quality indicators of a sour-milk product at different concentrations of sprouted beans flour;

- to learn the dependence of a change in active acidity, effective viscosity on the use of various concentrations of sprouted beans flour during the production of a sour-milk product.

\section{Methods, raw materials, and technologies used} in the study

4. 1. Studying the composition of goat and cow milk, investigating the influence of the content of Lactobacillus acidophilus and Bifidobacterium lactis cultures on a change in the quality indicators of a sour milk product

The study was carried out using the samples of milk from 80 goats of the "Zaanenska" breed and the samples of milk from 123 cows of the "Chervona-stepova" breed, grown on the farm "Granny's goats", Kyiv oblast, the village of Galaiki. The samples of daily milking were studied. The content of $\alpha s 1-\alpha s 2-$ and $\beta$-casein fraction was studied using the electrophoresis method with the help of the IFO-451 microphotometer ("Asma-prybor" LLC, Russia). Statistical data processing was carried out using the software environment Statistical 10.0.

The protein content in milk was determined by the colorimetric method, which is based on the ability of milk proteins at $\mathrm{pH}$ below the isoelectric point to bind the sour dye, forming insoluble sediment with it. After the sediment removal, the optical density of the original dye solution is measured in relation to the resulting solution, which decreases proportionally to the weight fraction of protein.

The samples were prepared as follows: $1 \mathrm{~cm}^{3}$ of milk was measured into the test tube, $20 \mathrm{~cm}^{3}$ of the working solution of a blue-black dye were added and the mixture was stirred intensively. The sediment was centrifuged and filtered. The resulting filtrate was diluted by 100 times and treated on the photocolorimeter KFK 3-01 (Zagorsky optical and mechanical plant, Russia) at the wavelength of $500-600 \mathrm{~nm}$ in a cuvette with the working length of $10 \mathrm{~mm}$. The weight fraction of proteins in milk was determined as a percentage, using the calibration graph.

The fat content in milk was determined by the sulfuric acid method. It is based on dissolving milk proteins with sulfuric acid, as a result of which fat is released in its pure form. The technique is described in paper [25]. The condition of the clot was determined organoleptically.

The objects of the study were the strains of microorganisms of acidophilic coli (Lactobacillus acidophilus) and bifidobacteria (Bifidobacterium lactis) and flour of sprouted beans. "Dietary soy flour enriched with iodine" TU U 10.6-0271205-001:2019, according to the documentation, is the carrier of $126 \mathrm{mg}$ of iodine in $100 \mathrm{~g}$. "Dietary chick-pea flour enriched with selenium" TU U 10.6-0271205-002:2019, according to the documentation, is the carrier of $70 \mathrm{mg}$ of selenium in $100 \mathrm{~g}$. The flour was used in the ratio of 1:1. Analysis of the content of bacteria Lactobacillus acidophilus, Bifidobacterium Lactis was conducted using the procedure described in paper [26]. Microphotography was carried out on a three-ocular fluorescent microscope of Microderm 3 LUM (Moscow, Russia). Bifidobacteria were explored at classical illumination by Keller, at a magnification of $16 \times 100$ times.

\section{2. Studying active acidity and effective viscosity in} a sour-milk product

Active acidity was determined by the potentiometric method at pH meter CT-6020 (Kelilong Instruments, China), with the range of measuring of the device of $0.0 \ldots 14.0 \mathrm{pH}$ units [27]. Effective viscosity was determined on the rotary viscosimeter "Reotest-2" according to the device instruction, according to the standard procedure [27].

\section{Results of research into the use of sprouted beans flour enriched with iodine and selenium during the production of a sour-milk product}

5. 1. Research into the content of basic protein fractions in goat and cow milk and the influence of casein fraction on sour-milk product

Results of the research into the content of basic protein fractions in goat and cow milk are shown in Table 1. The results of research into the influence of the content of $\alpha$ s1- and $\beta$-casein fraction on the technological properties of a sourmilk product are shown in Tables 2, 3 .

Table 1

Content of basic protein fractions in goat and cow milk

\begin{tabular}{|c|c|c|}
\hline \multirow{2}{*}{ Indicator } & \multicolumn{2}{|c|}{ Proteins and their fractions in milk } \\
\cline { 2 - 3 } & $\begin{array}{c}\text { Goat milk, g/100 ml } \\
n=80\end{array}$ & $\begin{array}{c}\text { Cow milk, g/100 ml } \\
n=123\end{array}$ \\
\hline Total protein & $3.196 \pm 0.040$ & $3.360 \pm 0.040^{* *}$ \\
\hline Casein fractions: & $2.452 \pm 0.037$ & $2.609 \pm 0.045^{* *}$ \\
\hline$\alpha s 1$ & $0.393 \pm 0.010$ & $0.859 \pm 0.025^{* * *}$ \\
\hline$\alpha s 2$ & $0.526 \pm 0.027^{* *}$ & $0.321 \pm 0.009$ \\
\hline \multicolumn{2}{|c|}{$1.122 \pm 0.014^{* * *}$} & $0.767 \pm 0.021$ \\
\hline Note: ${ }^{* * *}-p<0.001 ;{ }^{* *}-p<0.01 ;^{*}-P<0.05$
\end{tabular}

It was established that goat milk contains $0.393 \mathrm{~g}$ of as1-casein fractions in $100 \mathrm{ml}$, compared with cow milk, which contains $0.859 \mathrm{~g}$ in $100 \mathrm{ml}$, which is by $0.466 \mathrm{~g}$ less. Casein fractions $\alpha \mathrm{s} 2-$ in goat milk was $0.526 \mathrm{~g}$ in $100 \mathrm{ml}$, which is by $0.205 \mathrm{~g}$ less than the content of the studied casein in cow milk, which was $0.321 \mathrm{~g}$ in $100 \mathrm{ml}$. The content of $\beta$-casein faction in goat milk was $1.122 \mathrm{~g}$ in $100 \mathrm{ml}$, in cow milk, the figure was $0.767 \mathrm{~g}$ in $100 \mathrm{ml}$.

Consider the technological aspect of this study on the use of goat milk as a raw material for the production of a sour-milk product at high or low content of $\alpha$ s1- $\alpha$ s2- and $\beta$-casein fractions.

Table 2 shows the results of the research into the impact of the content of $\alpha$ s1-casein fraction on the technological properties of a sour-milk product.

Analyzing the content of $\alpha$ s1- casein fraction on the state of a clot in the sour milk product based on goat milk, it was established that the samples with a high content of $\alpha 1$ - casein fraction had the advantage in obtaining a desired dense clot. 33 samples of this kind were detected, which was $68.8 \%$, whereas the samples with the lower content of $\alpha$ s1casein fraction formed such a clot only in 15 samples, which amounted to $46.9 \%$.

Analyzing the content of the $\beta$ - casein fraction on the state of a clot in goat milk, it was found that the milk samples with the low content of $\beta$ - casein fractions had an advantage in obtaining a desired dense clot. 31 samples were detected, which made $66 \%$, whereas the samples with a larger content 
of $\beta$ - casein fraction formed this clot only in 17 samples, which made $51.6 \% .13$ and 3 research samples of goat milk with the content ranging from 1.103 to $0.901 \mathrm{~g}$ in $100 \mathrm{ml}$, which was 27.7 and $6.2 \%$, respectively, had a friable and ductile clot. In the samples with the content of $\beta$ - casein fraction in the range from 1.103 to $1.337 \mathrm{~g}$ in $100 \mathrm{ml}, 8$ samples had a friable and ductile state of a sour milk clot, which amounted to $24.2 \%$.

Table 2

Impact of the content of $\alpha$ s1-casein fraction on the technological properties of the sour-milk product

\begin{tabular}{|c|c|c|c|c|}
\hline \multirow{2}{*}{ Indicator } & \multicolumn{3}{|c|}{ Content of $\alpha_{\mathrm{s} 1}-$ casein fraction } \\
\cline { 2 - 5 } & \multicolumn{2}{|c|}{ High, $n=48$} & \multicolumn{2}{c|}{ Low, $n=32$} \\
\hline $\begin{array}{c}\text { Limits of } \alpha \mathrm{s} 1- \\
\text { content }\end{array}$ & \multicolumn{2}{|c|}{$0.393 \ldots .465 \mathrm{~g} / 100 \mathrm{ml}$} & $0.319 \ldots 0.392 \mathrm{~g} / 100 \mathrm{ml}$ \\
\hline Fat, \% & \multicolumn{2}{|c|}{$4.18 \pm 0.08^{*}$} & \multicolumn{2}{c|}{$3.88 \pm 0.09$} \\
\hline Protein, \% & \multicolumn{2}{|c|}{$3.32 \pm 0.04^{* *}$} & \multicolumn{2}{c|}{$3.12 \pm 0.03$} \\
\hline State of clot: & $\begin{array}{c}\text { Sample, } \\
\text { pcs. }\end{array}$ & $\%$ & $\begin{array}{c}\text { Sample, } \\
\text { pcs. }\end{array}$ & $\%$ \\
\hline dense & 33 & 68.8 & 15 & 46.9 \\
\hline Friable & 14 & 29.2 & 7 & 21.8 \\
\hline ductile & 1 & 2 & 10 & 31.4 \\
\hline
\end{tabular}

Note: ${ }^{* *}-p<0.001$; ${ }^{*}-P<0.05$

14 and 1 research samples of goat milk with a high content of $\alpha$ s1- casein fractions (the range of $0.393 \ldots 0.465 \mathrm{~g}$ in $100 \mathrm{ml}$ ), which made up 29 and $2 \%$, respectively, had a friable and ductile clot. In the samples with low content of as1- casein fraction (the range of $0.319 \ldots 0.392 \mathrm{~g}$ in $100 \mathrm{ml}$ ), 7 and 10 samples had the friable and ductile state of a clot, which made 21.8 and $31.4 \%$.

Table 3 shows the results of the research into the impact of the content of $\beta$-casein fraction on the technological properties of the sour-milk product.

Table 3

Influence of content of $\beta$ - casein fraction on the technological properties of the sour-milk product

\begin{tabular}{|c|c|c|c|c|}
\hline \multirow{2}{*}{ Indicator } & \multicolumn{3}{|c|}{ Content of $\beta$ - casein fraction } \\
\cline { 2 - 5 } & \multicolumn{2}{|c|}{ High, $n=33$} & \multicolumn{2}{|c|}{ Low, $n=47$} \\
\hline $\begin{array}{c}\text { Limits of content of } \\
\beta \text { - casein fraction }\end{array}$ & $\begin{array}{c}1.103 \ldots 1.337, \\
\mathrm{~g} / 100 \mathrm{ml}\end{array}$ & $\begin{array}{c}1.103 \ldots 0.901, \\
\mathrm{~g} / 100 \mathrm{ml}\end{array}$ \\
\hline Fat, \% & \multicolumn{2}{|c|}{$3.86 \pm 0.09$} & \multicolumn{2}{c|}{$4.2 \pm 0.05^{* *}$} \\
\hline Protein, \% & \multicolumn{2}{|c|}{$3.35 \pm 0.08^{*}$} & \multicolumn{2}{c|}{$3.09 \pm 0.06$} \\
\hline State of clot: & $\begin{array}{c}\text { Sample, } \\
\text { pcs. }\end{array}$ & $\%$ & $\begin{array}{c}\text { Sample, } \\
\text { pcs. }\end{array}$ & $\%$ \\
\hline dense & 17 & 51.6 & 31 & 66 \\
\hline friable & 8 & 24.2 & 13 & 27.7 \\
\hline ductile & 8 & 24.2 & 3 & 6.2 \\
\hline Note: ${ }^{* *}-p<0.001 ; *$ & $-p<0.01$ & & \\
\end{tabular}

Table 4 shows how different content of cultures Lactobacillus acidophilus and Bifidobacterium lactis influences a change in quality indicators of the sour-milk product at different concentrations of sprouted beans flour.

It was determined that it is advisable to use the strains of cultures of microorganisms Lactobacillus acidophilus and Bifidobacterium lactis in the ratio of 2:1 (experiment No. 3) at the concentration of sprouted beans flour in an amount of $2 \%$ of the product weight. The samples have a clean, sourmilk smell, sour-milk taste, and a hard clot and by $25.8 \%$ more bifidobacteria cells compared to the control sample. The sample (experiment No. 4) with the content of sprouted beans flour in the amount of $2.5 \%$, where the strains of cultures of microorganisms Lactobacillus acidophilus and Bifidobacterium lactis were used in the ratio of $3: 1$, had a $42.3 \%$ of bifidobacteria cell. This is a fairly good result in terms of specialized dietary purpose, but the pronounced taste of bifidoproducts, which according to the tasters reminded of medicines, can affect consumer preferences. In studies [28-30], it was determined that a consumer wants to see the usual organoleptic indicators in the products for special purposes.

\section{Table 4}

Influence of the content of cultures Lactobacillus acidophilus and Bifidobacterium lactis on a change in the quality indicators of sour-milk product at various concentrations of sprouted beans flour

\begin{tabular}{|c|c|c|}
\hline $\begin{array}{c}\text { No. of } \\
\text { experi- } \\
\text { ment }\end{array}$ & $X / Y$ & Quality indicator \\
\hline 1 & $(X)$ Control/(Y) 1:1 & $\begin{array}{l}\text { Clean, sour milk smell. Taste } \\
\text { of sour milk without a specific } \\
\text { aftertaste. White color with } \\
\text { creamy shade, uniform through- } \\
\text { out the whole mass. There is no } \\
\text { clot. Microscopy reveals } 9 \% \text { of } \\
\text { bifidobacterium cells }\end{array}$ \\
\hline 2 & $(X) 1.5 \% /(Y) 1: 1$ & $\begin{array}{c}\text { Clean, sour milk smell. Taste } \\
\text { of sour milk without a specific } \\
\text { aftertaste. Consistency of liquid } \\
\text { yogurt. Microscopy reveals } 20 \% \\
\text { of bifidobacterium cells }\end{array}$ \\
\hline 3 & (X) $2.0 \% /(Y) 2: 1$ & $\begin{array}{l}\text { Clean, sour milk smell. Pleasant } \\
\text { sour-milk taste. Consistency } \\
\text { of an even-edge clot. Split into } \\
\text { two phases of a clot and serum. } \\
\text { Microscopy reveals } 34.8 \% \text { of } \\
\text { bifidobacterium cells. }\end{array}$ \\
\hline 4 & (X) $2.5 \% /(Y) 3: 1$ & $\begin{array}{l}\text { Sour smell. Sour-milk taste with } \\
\text { the aftertaste characteristic } \\
\text { of bifid-containing products } \\
\text { (reminds of medicines). Clot } \\
\text { consistency is vitreous. Split } \\
\text { into two phases of a clot and se- } \\
\text { rum. Microscopy reveals } 42.3 \% \\
\text { of bifidobacterium cells }\end{array}$ \\
\hline
\end{tabular}

Microscopic analysis revealed that in the sample of experiment No. 1 there were $9 \%$ of bifidobacterium cells, and in the sample of experiment No. 2, their content is $11 \%$ higher. There are $34.8 \%$ of bifidobacteria cells in sample 3 , $42.3 \%$ of bifidobacteria cells in sample 4 , which is by $25.8 \%$ and $33.3 \%$ more than in the control sample.

It was established that the content of legumes flour from $1.5 \%$ of the weight of the product affects an increase in the amount of bifidobacteria in the sour-milk product.

5. 2. Studying the dependence of a change in active acidity, effective viscosity on the content of sprouted beans flour

The dependence of active acidity of effective viscosity in the sour-milk product on the use of different concentrations of sprouted beans flour was studied. The research results are shown in Table 5 and Fig. 1. 
Table 5

Dependence of a change in active acidity on the use of various concentrations of flour from sprouted beans during the production of a sour-milk product

\begin{tabular}{|c|c|c|c|c|c|c|}
\hline \multirow{2}{*}{$\begin{array}{c}\text { Experimental } \\
\text { sample }\end{array}$} & \multicolumn{6}{|c|}{ Time, hours } \\
\hline & 1 & 2 & 3 & 4 & 5 & 6 \\
\hline & \multicolumn{6}{|c|}{ Acidity, $(\mathrm{pH})$ units } \\
\hline Control & 6.46 & 5.82 & 5.08 & 4.96 & 4.8 & 4.72 \\
\hline \multicolumn{7}{|c|}{ Content of geminated legumes flour, \%: } \\
\hline 1.5 & 6.3 & 5.7 & 5.0 & 4.80 & 4.72 & 4.68 \\
\hline 2.0 & 6.1 & 5.63 & 4.96 & 4.76 & 4.69 & 4.60 \\
\hline 2.5 & 5.98 & 5.42 & 4.8 & 4.70 & 4.66 & 4.58 \\
\hline
\end{tabular}

It was established that at an increase in the content of sprouted beans flour during the production of the sourmilk product, active acidity in the process of fermentation increased. After 6 hours of fermentation (the time was established according to the classical production technology), active acidity was 4.68 ; 4.60 and $4.58 \mathrm{pH}$ units in the samples using $1.5 ; 2$ and $2.5 \%$ (respectively), which is by 0.04; 0.12 and 0.14 (respectively) $\mathrm{pH}$ units less than in the control sample.

Fig. 1 shows the dependence of effective viscosity on the shear rate gradient in the samples of the sour-milk product on the concentration of sprouted beans flour.

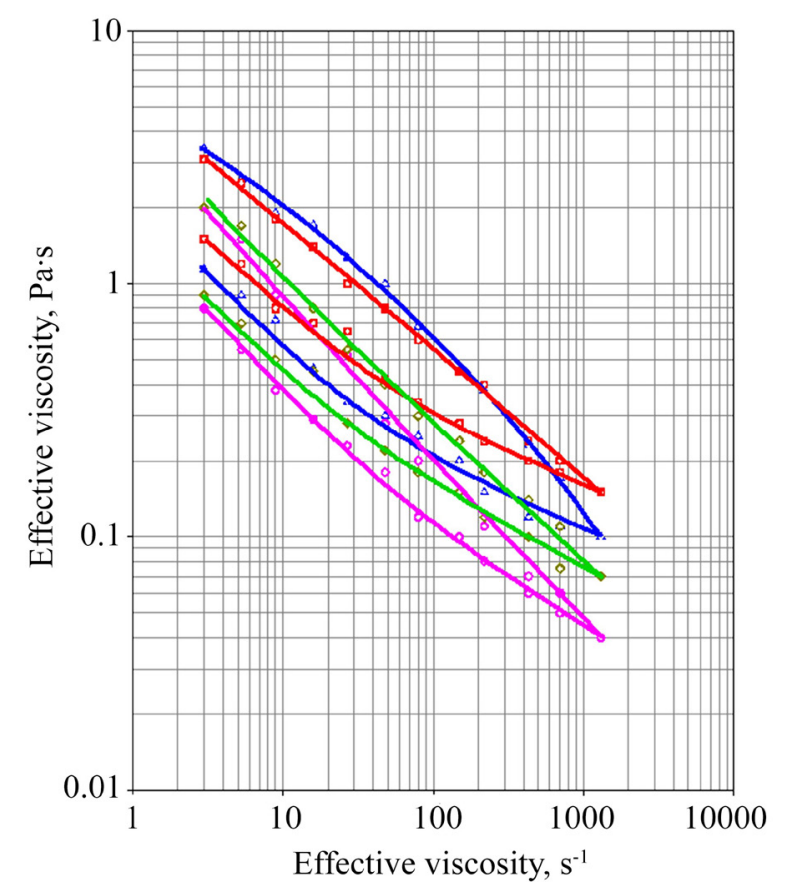

Fig. 1. Dependence of effective viscosity of shear rate gradient in the samples of the sour-milk product on the concentration of sprouted beans flour: red $-2.5 \%$; blue - control; green $-2.0 \%$; pink $-1.5 \%$

Research into the dependence of effective viscosity on the shear rate gradient showed that the curves in the flow of sour-milk products have the form of a hysteresis loop, which indicates a partial restoration of the structure. The use of flour from sprouted beans in the amount of 1.5 ...2.5\% reduces the area of the hysteresis loop, indicating more evi- dent thixotropic properties of the structure of the sour-milk product.

\author{
6. Discussion of the results of studying the use of \\ sprouted beans flour during the production of the sour- \\ milk product
}

After examining the content of the basic fractions of proteins in the milk of goats and cows, it was established that the differences between the fractional composition of goat and cow milk are observed in the content of casein fractions $-\alpha s 1, \alpha s 2$, and $-\beta$. Goat milk contains $0.393 \mathrm{~g}$ of $\alpha \mathrm{s} 1$ casein fractions in $100 \mathrm{ml}$, compared with cow milk, which contains 0.859 grams in $100 \mathrm{ml}$, which is by $0.466 \mathrm{~g}$ less. The fractions of casein $\alpha \mathrm{s} 2$ in goat milk were $0.526 \mathrm{~g}$ in $100 \mathrm{ml}$, which is by $0.205 \mathrm{~g}$ less than the content of the studied casein in cow milk, which was $0.321 \mathrm{~g}$ in $100 \mathrm{ml}$. The content of the $\beta$-casein faction in goat milk was $1.122 \mathrm{~g}$ in $100 \mathrm{ml}$, this indicator in cow milk reached $0.767 \mathrm{~g}$ in $100 \mathrm{ml}$ (Table 1). The low content of $\alpha$ s1 - casein fractions in goat milk will lead to the formation of a softer clot in the stomach, thus improving the activity of the digestive enzymes of proteases [31]. In women's breast milk, there is no fraction of $\alpha$ s1- casein, which leads to the lower \% of food disorders in newborns. Research [32] showed that milk with a high content of the given fraction ( $\alpha$ s1- casein) can be of great importance during the production of a sour-milk product. This is evidenced by the data presented in Table 2, where the content of $\alpha s 1-\alpha s 2-$ casein fraction of goat milk was explored.

Analyzing the influence of the content of $\alpha$ s1- casein fractions on the state of a sour-milk clot, it was determined that the samples with a high content of $\alpha$ s1- casein had an advantage in obtaining the desired dense clot over the samples with the lower content of $\alpha$ s1- casein fractions (Table 2).

In paper [33], the mechanism of this phenomenon is explained by the fact that goat milk has a smaller size of casein micelles than cow milk, which includes casein fractions $\alpha$ s1. This contributes to obtaining a denser clot in sour-milk products based on cow milk.

It may be concluded that a high content of $\alpha$ s1 casein in goat milk will affect the technological indicators of the sourmilk product in the direction of improving the structure of the finished product. And milk with the lower content of $\alpha \mathrm{s} 1$ casein will facilitate digestion and reduce the possibility of allergic manifestations in the human organism, which gives grounds for the development of the formulation of the premium hypoallergenic sour-milk product. The influence of the content of $\beta$-casein fraction on the technological properties of a sour-milk product was studied. It was established that milk samples with a low content of $\beta$-casein fractions had an advantage in obtaining the desired dense clot (Table 3 ).

$\beta$-caseins are known [34] to be useful for the human organism due to the absence of peptides that cause allergies in humans. Information on the impact of the content of $\beta$-caseins on the technological properties of sour-milk products was not found.

It was found experimentally that the strains of cultures of microorganisms Lactobacillus acidophilus and Bifidobacterium lactis in different ratios when using sprouted beans flour in the amount of $1.5 \ldots 2.5 \%$ of the weight of the product have clean, sour-milk smell, sour-milk taste, and a hard clot. The sample, where the strains of Lactobacillus acidophilus and Bifidobacterium Lactis microorganisms were used in 
the ratio of $3: 1$ with the content of sprouted beans flour in the amount of $2.5 \%$, had $42.3 \%$ of bifidobacteria cells. However, it was not "classic" in terms of smell and taste, with the pronounced aftertaste of bifid-containing products, which can affect the consumer advantages. It is rational to use the strains of Lactobacillus acidophilus and Bifidobacterium lactis organisms in the ratio of 2:1 at the concentration of sprouted beans flour in an amount of $2 \%$ of the product weight. At these ratios of the formulation components, the organoleptic indicators of the sour-milk product, which are usual for a consumer, were preserved.

Sprouted beans flour was not used in sample 1, and their content reached $1.5 \%$ of the product weight in sample 2 Table 4. Microscopic analysis revealed that there is a $9 \%$ bifidobacteria cell on the sample of experiment No. 1, and their content is $11 \%$ higher in the sample of experiment No. 2. Two experimental samples (No. 1,2) used cultures Lactobacillus acidophilus and Bifidobacterium lactis in the same amount and at the same ratio. Assume that the content of sprouted beans flour influences the vital activity of Bifidobacteria in the sour-milk product based on goat milk.

The dependence of a change in active acidity and effective viscosity on the content of the sprouted beans flour in the sour milk product was explored. A characteristic feature of sour-milk products is that at a change in the formulation ingredients even in insignificant quantities, their rheological characteristics change. It was determined that after 6 hours of fermentation in the samples using 1.5; 2 and $2.5 \%$ of sprouted beans flour, it amounted to $4.68 ; 4.60$ and $4.58 \mathrm{pH}$ units (respectively), which is by $0.04 ; 0.12$ and $0.14 \mathrm{pH}$ units lower than in the control sample Table 5 . The increase in acidity content is explained by the existence of sprouted beans flour. At an increase in the percentage of flour, active acidity increases, indicating the stimulating properties of flour, which affect the microflora, in particular, the content of bifidobacteria, at an increase of which, acidity increases.

The dependence of effective viscosity on the shear rate gradient was studied. It was established that the flow curves have the shape of a hysteresis loop, indicating the partial restoration of the structure. Fig. 1 shows that the area of the hysteresis loop in the control sample is greater than in other samples, which means that the use of flour from sprouted beans is positive in terms of improving the rheological properties of the product. Adding sprouted beans flour reduces the area of the hysteresis loop, indicating that the thixotropic properties of the structure are more pronounced. However, in general, they are commensurate when adding a different content percentage. This shows the absence of the expressed modification of the structure modification at the increased content of sprouted beans flour, which is valuable, taking into consideration the task of making the products of special products with preservation of organoleptic indicators that are usual for a consumer.

This study is limited to the rational use of the strains of Lactobacillus acidophilus and Bifidobacterium lactis micro- organisms in the ratio of 2:1 at the concentration of sprouted beans flour in the amount of up to $2 \%$ of the product weight. At this ratio, the products have classic organoleptic indicators and the increased content of bifidobacteria. An increase in the concentrations will lead to worsening the organoleptic indicators of the product, and as a consequence, to a decrease in demand and economic effect from production.

The prospect of the subsequent research is to study the content of iodine and selenium preservation during the storage of the sour-milk product in order to provide recommendations on the amount of daily consumption of the developed product

\section{Conclusions}

1. Milk of goats and cows differs by the content of $\alpha s 1-\alpha s 2-\beta$ - casein fractions of proteins. Goat milk contains $0.466 \mathrm{~g}$ in $100 \mathrm{ml}$, fewer $\alpha \mathrm{s} 1$ - casein fractions, and by $0.205 \mathrm{~g}$ less $\alpha \mathrm{s} 2$-casein fractions in $100 \mathrm{ml}$ compared to cow milk. The content of the $\beta$-casein faction in goat milk is by $0.355 \mathrm{~g}$ in $100 \mathrm{ml}$ higher than in cow milk. The content of $\alpha$ s1- casein fraction of goat milk influences the state of a sour-milk clot. The samples with a high content of as1- casein fractions had the advantage of obtaining a desired dense clot. There were 33 such samples, which made $68.8 \%$, while only 15 samples with a lower content of $\alpha 1$ - casein fraction, which made up $46.9 \%$, formed such a clot. The content of $\beta$ - casein fraction of goat milk influences the state of a sour-milk clot. The samples of milk with low content of $\beta$ - casein fraction had the advantage in obtaining the desired clot density. There were 31 such samples, which made up $66 \%$. Only 17 samples with a higher content of $\beta$ - casein fraction, which made up $51.6 \%$, formed a dense clot. The influence of Lactobacillus acidophilus and Bifidobacterium lactis cultures on a change in quality indicators of the sour-milk product at different concentrations of sprouted beans flour was found. The strains of cultures of Lactobacillus acidophilus and Bifidobacterium lactis microorganisms were used rationally in the ratio of $2: 1$ at the concentration of sprouted beans flour in the amount of $2 \%$ to the product weight. The samples had a clean, sour-milk smell, sour-milk taste, and a hard clot. They also had $25.8 \%$ more bifidobacteria cells compared to the control sample.

2 . The dependences of a change in active acidity, effective viscosity on the use of various concentrations of sprouted beans flour during the production of a sour-milk product were obtained. It was established that active acidity in the process of fermentation was $4.68 ; 4.60$ and $4.58 \mathrm{pH}$ units in the samples using 1.5 ; 2 and $2.5 \%$, respectively, which is by $0.04,0.12$ and 0.14 (respectively) $\mathrm{pH}$ units lower than in the control sample. The use of sprouted beans flour in the amount of $1.5 \ldots 2.5 \%$ reduces the area of the hysteresis loop, which indicates more pronounced thixotropic properties of the structure of a sour-milk product in comparison with the control sample.

\section{References}

1. Beletska, Y., Plotnikova, R., Bakirov, M., Vereshchynskyi, O. (2020). Development of the technology of soya flour enriched with iodine. Food Science and Technology, 14 (2), 87-95. doi: https://doi.org/10.15673/fst.v14i2.1487

2. Moliboga, E. A. (2016). Expansion of variety line of functional food products by developing technologies of processed cheese product for specialized nutrition. Agrarniy vestnik Urala, 05 (147), 75-77. 
3. Biletska, Y., Plotnikova, R., Danko, N., Bakirov, M., Chuiko, M., Perepelytsia, A. (2019). Substantiation of the expediency to use iodine-enriched soya flour in the production of bread for special dietary consumption. Eastern-European Journal of Enterprise Technologies, 5 (11 (101)), 48-55. doi: https://doi.org/10.15587/1729-4061.2019.179809

4. Biletska, Y., Plotnikova, R., Skyrda, O., Bakirov, M., Iurchenko, S., Botshtein, B. (2020). Devising a technology for making flour from chickpea enriched with selenium. Eastern-European Journal of Enterprise Technologies, 1 (11 (103)), 50-58. doi: https://doi.org/ 10.15587/1729-4061.2020.193515

5. Biletska, Y., Djukareva, G., Ryzhkova, T., Kotlyar, O., Khaustova, T., Andrieieva, S., Bilovska, O. (2020). Substantiating the use of germinated legume flour enriched with iodine and selenium in the production of cooked-smoked sausages. Eastern-European Journal of Enterprise Technologies, 3 (11 (105)), 46-54. doi: https://doi.org/10.15587/1729-4061.2020.204796

6. Rumiantsev, R. Ye. (2015). Analiz rynku molochnykh produktiv v Ukraini. Yevropeiski perspektyvy, 5, 26-31. Available at: http:// nbuv.gov.ua/j-pdf/evpe_2015_5_6.pdf

7. Garneau, S., Martin, N. I., Vederas, J. C. (2002). Two-peptide bacteriocins produced by lactic acid bacteria. Biochimie, 84 (5-6), 577-592. doi: https://doi.org/10.1016/s0300-9084(02)01414-1

8. Popova, M. A., Rebezov, M. B., Ahmed'yarova, R. A. et. al. (2014). Perspektivnye napravleniya proizvodstva kislomolochnyh produktov, v chastnosti yogurtov. Young Scientist, 9 (68), 196-199. Available at: https://moluch.ru/archive/68/11524/

9. Gilmutdinova, L. T., Yanturina, N. H., Kudayarova, R. R., Kamaletdinov, S. H., Yamaletdinov, K. S., Ahmadullin, R. V., Gabdelhakova, L. A. (2010). Use the product mares milk in rehabilitation of patients with ischemic heart disease. Bulletin of Siberian Medicine, 9 (3), 121-124. doi: https://doi.org/10.20538/1682-0363-2010-3-121-124

10. Shuvarikov, A. S., Yurova, E. A., Pastukh, O. N. (2017). Quality indicators of cow, goat and camel milk with account of allergenicity. Izvestiâ Timirâzevskoj Sel'skohozâjstvennoj Akademii, 5, 115-123. doi: https://doi.org/10.26897/0021-342x-2017-5-115-123

11. Abisheva, T. O., Ashirova, Zh. B., Ramazanova, A. A. (2015). Biologicheskie i lechebnye svoystva kumysa. Mir sovremennoy nauki, 2 (30), 15-20. Available at: https://www.elibrary.ru/item.asp?id=23925289

12. Akaev, N. Dabuzova, G. (2007). Molochnaya produktivnost', himicheskiy sostav i svoystva moloka ovets dagestanskoy gornoy porody vo vtoroy polovine laktatsii pri otgonno-pastbishchnom soderzhanii. Sel'skohozyaystvenniy zhurnal, 2 (2-2), 3-5. Available at: https://cyberleninka.ru/article/n/molochnaya-produktivnost-himicheskiy-sostav-i-svoystva-moloka-ovets-dagestanskoy-gornoyporody-vo-vtoroy-polovine-laktatsii-pri-otgonno

13. Lesnovskaya, E. V. (2014). Biochemical composition and usefulness of sheep milk. Naukovyi visnyk Lvivskoho natsionalnoho universytetu veterynarnoi medytsyny ta biotekhnolohiy imeni S.Z. Gzhytskoho, 16 (3 (60)), 82-87. Available at: https:// cyberleninka.ru/article/n/biohimicheskiy-sostav-i-polnotsennost-moloka-ovets/viewer

14. Kaskous,S.(2016). Importance of camel milk for human health.Emirates JournalofFoodand Agriculture,28(3), 158.doi:https://doi.org/ 10.9755/ejfa.2015-05-296

15. Mongush, S. D. (2019). Technological properties of camel milk in different lactation periods. Vestnik Hakasskogo gosudarstvennogo universiteta im. N. F. Katanova, 2 (28), 86-89. Available at: https://cyberleninka.ru/article/n/tehnologicheskie-svoystva-molokaverblyudov-v-raznye-periody-laktatsii

16. Greppi, G. F., Roncada, P., Fortin, R. (2008). Protein components of goat's milk. Dairy goats feeding and nutrition, 71-94. doi: https://doi.org/10.1079/9781845933487.0071

17. Fatikhov, A. G., Haertdinov, R. A. (2016). Technological properties goat milk. Uchenye zapiski Kazanskoy gosudarstvennoy akademii veterinarnoy meditsiny im. N.E. Baumana, 226, 217-220. Available at: https://cyberleninka.ru/article/n/tehnologicheskie-svoystvakoziego-moloka/viewer

18. Ryzhkova, T., Bondarenko, T., Dyukareva, G., Biletskaya, Y. (2017). Development of a technology with an iodine-containing additive to produce kefir from goat milk. Eastern-European Journal of Enterprise Technologies, 3 (11 (87)), 37-44. doi: https://doi.org/10.15587/1729-4061.2017.103824

19. Fatikhov, A. G., Haertdinov, R. A. (2017). Influence of the level of content of $\alpha \mathrm{S} 1$ - and $\beta$-casesins in goat milk on its allergenic, thermostable, suitability of cheese properties. Uchenye zapiski Kazanskoy gosudarstvennoy akademii veterinarnoy meditsiny im. N.E. Baumana, 230, 163-167. Available at: https://cyberleninka.ru/article/n/vliyanie-urovnya-soderzhaniya-s1-i-kazeinov-vkoziem-moloke-na-ego-allergennye-termostabilnye-i-syrodelcheskie-svoystva/viewer

20. Maurer, J., Berger, T., Amrein, R., Schaeren, W. (2013). Critères de qualité pour le lait de chèvre et de brebis. ALP forum, 97, 1-16.

21. Fuller, R., Gibson, G. R. (1998). Probiotics and prebiotics: microflora management for improved gut health. Clinical Microbiology and Infection, 4 (9), 477-480. doi: https://doi.org/10.1111/j.1469-0691.1998.tb00401.x

22. Gibson, G. R., Fuller, R. (2000). Aspects of In Vitro and In Vivo Research Approaches Directed Toward Identifying Probiotics and Prebiotics for Human Use. The Journal of Nutrition, 130 (2), 391S-395S. doi: https://doi.org/10.1093/jn/130.2.391s

23. Belyakova, S. Y., Krasnikova, L. V. (2014). Synbiotic fermented milk product with vegetable fillers for powering children of school age. Nauchniy zhurnal NIU ITMO. Seriya «Ekonomika i ekologicheskiy menedzhment», 1. Available at: http://economics.ihbt.ifmo.ru/ file/article/8840.pdf 
24. Russell, D. A., Ross, R. P., Fitzgerald, G. F., Stanton, C. (2011). Metabolic activities and probiotic potential of bifidobacteria. International Journal of Food Microbiology, 149 (1), 88-105. doi: https://doi.org/10.1016/j.ijfoodmicro.2011.06.003

25. Vyznachennia zhyru v molotsi. Available at: https://studfile.net/preview/6725704/page:37/

26. GOST 33951-2016. Milk and milk products. Methods for determination of the lactic acid bacteria. Available at: http://docs.cntd.ru/ document $/ 1200142430$

27. Stoliarchuk, P., Malyk, O. (2011). Implementation of the control system of dairy products - bail of quality and safety. Standartyzatsiya. Sertyfikatsiya. Yakist, 6, 61-64. Available at: http://www.irbis-nbuv.gov.ua/cgi-bin/irbis_nbuv/cgiirbis_64.exe?C21COM=2\&I21D $\mathrm{BN}=\mathrm{UJRN} \& \mathrm{P} 21 \mathrm{DBN}=\mathrm{UJRN} \& I M A G E \_F I L E \_D O W N L O A D=1 \& I m a g e \_f i l e \_n a m e=P D F / s s i a \_2011 \_6 \_18 . p d f$

28. Biletska, Y., Babenko, V., Gusliev, A. (2019). Marketing studies of consumption preferences at developing dietary products. EUREKA: Social and Humanities, 5, 16-21. doi: https://doi.org/10.21303/2504-5571.2019.001009

29. Hrynko, P., Grinko, A. (2020). Methodological approaches to modeling information architecture of the organization in the conditions of digital economy. EUREKA: Social and Humanities, 1, 27-34. doi: https://doi.org/10.21303/2504-5571.2020.001137

30. Biletska, Y., Pysarevskiy, M., Sokolovska, O., Grigorova-Berenda, L. (2020). Marketing research and design of quality function in the production of innovative product of health purpose. Technology Audit and Production Reserves, 3 (4 (53)), 41-44. doi: https://doi.org/10.15587/2706-5448.2020.203738

31. Silanikove, N., Leitner, G, Merin, U, Prosser, C. (2010). Recent advances in exploiting goat's milk: Quality, safety and production aspects. Small Ruminant Research, 89 (2-3), 110-124. doi: https://doi.org/10.1016/j.smallrumres.2009.12.033

32. Kuz'menko, N. B., Kuzina, A. N. (2016). Rol' beta-kazeina v pitanii detey pervyh let zhizni. Lechashchiy vrach, 1, 16-19.

33. Ceballos, L. S., Morales, E. R., de la Torre Adarve, G., Castro, J. D., Martínez, L. P., Sampelayo, M. R. S. (2009). Composition of goat and cow milk produced under similar conditions and analyzed by identical methodology. Journal of Food Composition and Analysis, 22 (4), 322-329. doi: https://doi.org/10.1016/j.jfca.2008.10.020

34. Raynal-Ljutovac, K., Lagriffoul, G., Paccard, P., Guillet, I., Chilliard, Y. (2008). Composition of goat and sheep milk products: An update. Small Ruminant Research, 79 (1), 57-72. doi: https://doi.org/10.1016/j.smallrumres.2008.07.009 